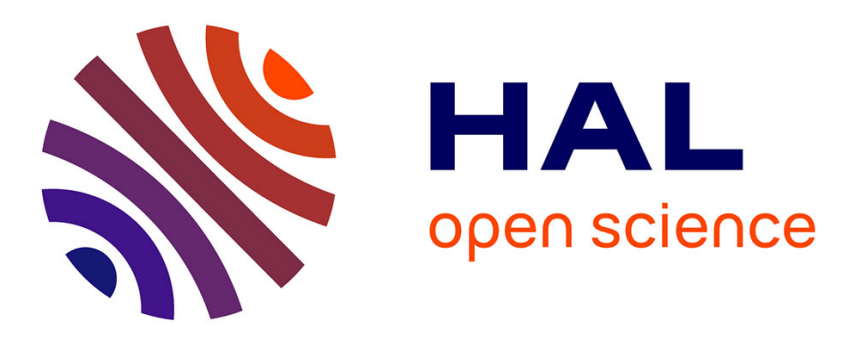

\title{
Role of collagenase in mediating in vitro alveolar epithelial wound repair.
}

\author{
Emmanuelle Planus, Stéphane Galiacy, Michael Matthay, Valérie M. Laurent, \\ Jelena Gavrilovic, Gillian Murphy, Christine Clérici, Daniel Isabey, Chantal \\ Lafuma, Marie-Pia d'Ortho
}

\section{To cite this version:}

Emmanuelle Planus, Stéphane Galiacy, Michael Matthay, Valérie M. Laurent, Jelena Gavrilovic, et al.. Role of collagenase in mediating in vitro alveolar epithelial wound repair.. Journal of Cell Science, 1999, 112 ( Pt 2), pp.243-52. inserm-00186823

\section{HAL Id: inserm-00186823 https://www.hal.inserm.fr/inserm-00186823}

Submitted on 19 Nov 2009

HAL is a multi-disciplinary open access archive for the deposit and dissemination of scientific research documents, whether they are published or not. The documents may come from teaching and research institutions in France or abroad, or from public or private research centers.
L'archive ouverte pluridisciplinaire HAL, est destinée au dépôt et à la diffusion de documents scientifiques de niveau recherche, publiés ou non, émanant des établissements d'enseignement et de recherche français ou étrangers, des laboratoires publics ou privés. 


\title{
Role of collagenase in mediating in vitro alveolar epithelial wound repair
}

\author{
Emmanuelle Planus ${ }^{1, *}$, Stéphane Galiacy ${ }^{1}$, Michael Matthay ${ }^{2}$, Valérie Laurent ${ }^{1}$, Jelena Gavrilovic ${ }^{3}$, \\ Gillian Murphy ${ }^{3}$, Christine Clérici $^{4}$, Daniel Isabey ${ }^{1}$, Chantal Lafuma ${ }^{1}$ and Marie-Pia d'Ortho ${ }^{1,5}$ \\ ${ }^{1}$ Unité INSERM U492, Faculté de Médecine, 8 rue du Général Sarrail, 94010 Créteil, France \\ ${ }^{2}$ Cardiovascular Research Institute, UCSF, San Francisco, CA 94143-0130, USA \\ ${ }^{3}$ School of Biological Sciences, University of East Anglia, Norwich NR4 7TJ, UK \\ ${ }^{4}$ Laboratoire de Physiologie, UFR de Santé, Université Paris XIII, 93000 Bobigny, France \\ 5 Service de Physiologie-Exploration Fonctionnelles, Hôpital Henri Mondor, 94010 Créteil, France \\ *Author for correspondence (e-mail: planus@im3.inserm.fr)
}

Accepted 10 November; published on WWW 21 December 1998

\section{SUMMARY}

Type II pneumocytes are essential for repair of the injured alveolar epithelium. The effect of two MMP collagenases, MMP-1 and MMP-13 on alveolar epithelial repair was studied in vitro. The A549 alveolar epithelial cell line and primary rat alveolar epithelial cell cultures were used. Cell adhesion and cell migration were measured with and without exogenous MMP-1. Wound healing of a cell monolayer of rat alveolar epithelial cell after a mechanical injury was evaluated by time lapse video analysis. Cell adhesion on type I collagen, as well as cytoskeleton stiffness, was decreased in the presence of exogenous collagenases. A similar decrease was observed when cell adhesion was tested on collagen that was first incubated with MMP-1 (versus control on intact collagen). Cell migration on type I collagen was promoted by collagenases.
Wound healing of an alveolar epithelial cell monolayer was enhanced in the presence of exogenous collagenases. Our results suggest that collagenases could modulate the repair process by decreasing cell adhesion and cell stiffness, and by increasing cell migration on type I collagen. Collagen degradation could modify cell adhesion sites and collagen degradation peptides could induce alveolar type II pneumocyte migration. New insights regarding alveolar epithelial cell migration are particularly relevant to investigate early events during alveolar epithelial repair following lung injury.

Key words: Collagenase, Alveolar epithelial cell, Extracellular matrix, Cell migration, Cytoskeleton, Cell stiffness, Alveolar repair

\section{INTRODUCTION}

Acute lung injury is characterized by lesions of both lung endothelial and alveolar epithelial cells leading in more severe cases to complete denudation of epithelial basement membranes. During this acute phase, basement membranes are also damaged with deposition of a provisional extracellular matrix made of fibrinogen, fibronectin and fibrillar collagens (Anderson and Thielen, 1992). Reconstitution of the alveolocapillary barrier depends on a combination of events including proliferation of alveolar epithelial type II cell and their differentiation into type I pneumocytes. Re-epithelialization not only involves cellular proliferation and differentiation, but also cellular locomotion as well. These processes are necessarily accompanied by digestion of the provisional matrix allowing its replacement by normal basement membranes, made of type IV collagen, laminin and nidogen. All of these events would lead in the most favorable case to restoration of the normal alveolo-capillary barrier.

By cleaving extracellular matrix components, we hypothesized that matrix metalloproteinases (MMPs), especially collagenases, which cleave fibrillar collagens, could play a role in the repair of the alveolar epithelium. MMPs are a multigenic family of enzymes specialized in extracellular matrix degradation. Based on substrate specificity and sequence similarities, MMPs are divided into subclasses including collagenases, stromelysins, metallo-elastase, gelatinases (Murphy and Reynolds, 1993), and membrane type-MMPs (Sato et al., 1994). MMPs are inhibited by the four members of the tissue inhibitor of matrix metalloproteinase (TIMP) family, TIMP-1, $-2,-3$ and -4 (Murphy and Reynolds, 1993). Three different collagenases have been described, the fibroblast collagenase, MMP-1, the neutrophil collagenase, MMP-8, and more recently collagenase-3, MMP-13, cloned from a breast tumor library (Freije et al., 1994). Collagenases have a unique feature among mammalian proteinases as triple helicases, which allows the cleavage of all three chains of fibrillar collagens at a single locus. The fragments generated are approximately $3 / 4$ and $1 / 4$ of the total length of the native molecule. The production of MMPs and TIMPs by alveolar epithelial cells have been demonstrated both in vivo and in vitro (d'Ortho et al., 1997a,b; Pardo et al., 1997), particularly the production of interstitial collagenase (Pardo et al., 1997). The latter was increased following acute lung injury induced by hyperoxia (Pardo et al., 1996), suggesting a possible contribution to the pathophysiology of the disease. 
To examine the possible role of collagenases in alveolar epithelial repair, we carried out several in vitro assays which test cellular events involved in the repair, particularly cell adhesion and migration on fibrillar type I collagen. The results were then compared to those obtained in the presence of exogenous collagenases. Using magnetocytometry, the effect of exogenous collagenases was also tested on cytoskeletal stiffness. Finally, exogenous collagenases were tested on in vitro wound healing using primary culture of rat alveolar epithelial cells. Alveolar epithelial cells adherence to type I collagen was decreased by MMP collagenases, an effect which depended on collagenolysis. In addition, collagenases promoted cell migration. Magnetocytometry further confirmed alterations in cell-collagen interactions by exogenous collagenases as indicated by a decrease in cytoskeleton stiffness. Finally, collagenases induced the closure of an in vitro wound analogous to what occurs using serum-enriched culture medium. These results support the hypothesis that MMP collagenases play an important role in alveolar epithelial repair. By degrading the fibrillar collagens present in the provisional matrix, the collagenases modify interactions between alveolar epithelial cells and the extracellular matrix, and therefore promote cell migration and alveolar re-epithelialization.

\section{MATERIALS AND METHODS}

\section{Reagents}

DNase I, insulin, transferrin, tri-iodothyronine and rhodaminated phalloidin were obtained from Sigma Chemicals (L'Ile d'Abeau Chêne, France). Elastase was purchased from Worthington (Paris, France). DMEM, glutamine, fetal calf serum (FCS), newborn calf serum and antibiotics used for cultures were obtained from Gibco BRL (Cergy-Pontoise, France). Type I collagen from rat tail was obtained from Becton Dickinson (Le Perray en Yvelines, France). The synthetic inhibitor of MMPs, BB-3103, was a generous gift from British Biotech (Slough, UK). Transwell ${ }^{\circledR}$ chambers were from Costar (Badhoevedorp, The Netherlands).

\section{Expression and purification of MMP-1, MMP-13 and TIMP-1}

Pro-MMP-1, pro-MMP-13 and TIMP-1 were expressed by stable transfection of NSO mouse myeloma cells and purified from serumfree conditioned cell culture medium, as previously described (Knäuper et al., 1996a; Murphy et al., 1991, 1992). Activation of proMMP-1 was done by incubating the enzyme in the presence of $1 \mathrm{mM}$ APMA at $37^{\circ} \mathrm{C}$. APMA was dialyzed subsequently.

Cleavage of fibrillar type I collagen was done in vitro just before cell assays by incubating type I collagen in the presence of pro-MMP1 at a molar ratio of $20: 1$ for 18 hours, at $25^{\circ} \mathrm{C}$, with $1 \mathrm{mM}$ aminophenylmercuric acetate (used as an in vitro activator of proMMPs), in $50 \mathrm{mM}$ Tris- $\mathrm{HCl}, \mathrm{pH} 7.4,150 \mathrm{mM} \mathrm{NaCl}, 5 \mathrm{mM} \mathrm{CaCl}{ }_{2}$.

\section{Cell cultures}

Isolation and primary culture of alveolar epithelial cells

Alveolar type II cells were isolated from pathogen-free male Sprague-Dawley rats as described previously (Clerici et al., 1992). Rats were injected with $30 \mathrm{mg} / \mathrm{kg}$ i.p. pentobarbital sodium and 1 i.u./g i.v. heparin sodium. After tracheotomy, each rat was exsanguinated. Solution II (40-50 ml) containing (mM) $140 \mathrm{NaCl}$, $5 \mathrm{KCl}, 2.5$ phosphate-buffered saline (PBS), $10 \mathrm{~N}-2$ hydroxymethylpiperazine- $N$-2-ethanesulfonic acid (Hepes), $2 \mathrm{CaCl}_{2}$, and $1.3 \mathrm{MgSO}_{4}, \mathrm{pH} 7.40$, at $37^{\circ} \mathrm{C}$ was infused through the air-filled lungs via the pulmonary artery to flush the blood out of the vascular bed. The lungs were then removed from the thorax and lavaged to total lung capacity $(10 \mathrm{ml})$, first five times with Solution I containing $(\mathrm{mM})$ $140 \mathrm{NaCl}, 5 \mathrm{KCl}, 2.5 \mathrm{PBS}, 10$ Hepes, $6 \mathrm{D}$-glucose, and 0.2 ethylene diamine tetraacetic acid tetrasodium salt (EDTA) to remove alveolar macrophages, then twice with Solution II. The lungs were then filled with $10 \mathrm{ml}$ of elastase solution (porcine pancreas, crystallized twice, 40 i.u./ml, prepared in Solution II) and incubated in a shaking water bath in physiologic saline for 20 minutes at $37^{\circ} \mathrm{C}$. After instillation of an additional $5 \mathrm{ml}$ of elastase solution, the lungs were incubated for 10 minutes. The lungs were minced in the presence of DNase I, and 5 $\mathrm{ml}$ of newborn calf serum was added to stop the effect of elastase. The lungs were then sequentially filtered through 150 and $30 \mu \mathrm{m}$ nylon mesh. The filtrate was centrifuged at $300 \mathrm{~g}$ for 8 minutes. The cell pellet was resuspended in DME medium containing $25 \mathrm{mM}$ D-glucose, at $37^{\circ} \mathrm{C}$. The cell suspension was plated on bacteriologic plastic dishes to help remove macrophages by differential adherence. After a 1 hour incubation at $37^{\circ} \mathrm{C}$ in a $5 \% \mathrm{CO}_{2}-95 \%$ air incubator, unattached cells in suspension were removed and centrifuged at $300 \mathrm{~g}$ for 8 minutes. The resulting cell pellet $\left(>95 \%\right.$ viability, $20-30 \times 10^{6}$ cells/rat) was plated at a density of $0.5 \times 10^{6} / \mathrm{cm}^{2}$ on 24-well culture plates. Culture medium was DMEM containing 10\% FCS, $2 \mathrm{mM}$ L-glutamine, 50 i.u. $/ \mathrm{ml}$ penicillin, $50 \mu \mathrm{g} / \mathrm{ml}$ streptomycin. Cultures plates were incubated in a $5 \% \mathrm{CO}_{2}-95 \%$ air incubator. After 24 hours, the culture medium was changed for a serum-free defined medium composed of DMEM supplemented with $2 \mathrm{mM} \mathrm{L}$-glutamine, 50 i.u./ml penicillin, $50 \mu \mathrm{g} / \mathrm{ml}$ streptomycin, $10 \mu \mathrm{g} / \mathrm{ml}$ insulin, $10 \mu \mathrm{g} / \mathrm{ml}$ transferrin, and $5 \times 10^{-9} \mathrm{M}$ tri-iodothyronine. Confluence was reached within 48 hours.

Preparation of A549 alveolar epithelial cells

A549 human alveolar epithelial cells (American Type Culture Collection, Rockville, MD) were grown to confluence in DMEM containing 10\% FCS, 2 mM L-glutamine, 50 i.u./ml penicillin, $50 \mu \mathrm{g} / \mathrm{ml}$ streptomycin, and incubated in a $5 \% \quad \mathrm{CO}_{2}-95 \%$ air atmosphere. Routine subcultures (passages 89 to 92 ) were done at one-third split ratios by incubation with $0.025 \mathrm{~g} \%$ trypsin- $0.02 \mathrm{~g} \%$ EDTA in calcium-and-magnesium-free PBS for 10 minutes at $37^{\circ} \mathrm{C}$.

\section{Cell attachment assay}

Cell attachment assays were performed as described by Aumailley and Timpl (1986). Briefly, 96-wells tissue culture plates were coated for 1 hour at RT with type I collagen, washed several time and blocked with $1 \%$ of BSA in DMEM for an additional 30 minutes. Cells were trypsinized off flasks, centrifuged and resuspended in DMEM with $1 \%$ BSA. The block was washed with DMEM and wells filled with $50 \times 10^{3}$ cells/well in DMEM-1\% BSA. Cells were allowed to attach for 1 hour at $37^{\circ} \mathrm{C}$, as determined by preliminary time course experiments. Unattached cells were discarded and washed three times with DMEM-1\% BSA. Attached cells were fixed with $4 \%$ paraformaldehyde for 30 minutes and stained with $1 \%$ Methylene Blue in $0.01 \mathrm{M}$ borate for 30 minutes. Excess dye was washed off with water and bound cells were lysed with EtOH/0.1 M HCl (1:1). The absorbance $(A)$ of released dye was read at $650 \mathrm{~nm}$ on a multiwell plate reader (SOFTmax).

\section{Cytoskeleton stiffness measured by magnetocytometry}

Cytoskeleton (CSK) stiffness was assessed by magnetocytometry (MTC) using a device, developed by D. Isabey (Laurent et al., 1998), similar to the one previously described by Wang et al. (1993a,b). The technique uses RGD-coated ferromagnetic microbeads in association with a magnetic twisting device which allows application of controlled mechanical stresses directly to cell-surface through integrins and, hence, to the CSK (Ingber, 1991). The degree of bead rotation, which is proportional to the CSK stiffness, is measured by an on-line magnetometer.

Bacteriologic dishes (96-well) were coated with type I collagen at a concentration of $5 \mu \mathrm{g} / \mathrm{cm}^{2}$ for 1 hour at RT. Cells were plated at the density of $50 \times 10^{3} /$ well in serum free medium with $1 \%$ BSA or in medium containing either pro-MMP-1or pro-MMP-13. 
Carboxyl ferromagnetic beads (4.0-4.5 $\mu \mathrm{m}$ diameter, Spherotec Inc., IL USA) were coated with arginine-glycin-aspartic acid (RGD) peptide following the company procedure (Telios Pharmaceuticals Inc., CA USA). Before used, coated-beads were incubated in serum free medium supplemented with $1 \%$ BSA for at least 30 minutes at $37^{\circ} \mathrm{C}$ to block non-specific binding. Beads were then added to the cells (40 $\mu \mathrm{g}$ per well) for 20 minutes at $37^{\circ} \mathrm{C}$ in a $5 \% \mathrm{CO}_{2}-95 \%$ air incubator. Unbound beads were washed away with serum free medium-1\% BSA supplemented with $25 \mathrm{mM}$ Hepes. Wells were placed into the magnetocytometer. A brief 1500 gauss magnetic pulse was applied to magnetize all surface bound beads in a unique horizontal direction, then a magnetic torque was generated by applying an orthogonal uniform magnetic field (42 gauss). Associated changes in angular strain of the beads were measured by an on-line magnetometer and subsequently transformed into analogic data with an acquisition system (AcqknowledgeIII, BIOPAC Inc., CA USA). Stiffness was defined as the ratio of stress to angular strain. This ratio measures the cell capability to resist to a local deformation, hence measures the CSK stiffness. Cytochalasin D (cyto D) is routinely used in magnetocytometry experiments as an internal control since it induces a marked decrease in CSK stiffness by disrupting filamentous actin (Wang et al., 1993a). Following the previous 24 hour incubation with or without collagenase, cell stiffness was measured by MTC, then cyto D was added for 20 minutes and cell stiffness measured again. The difference of cell stiffness before and after cyto D was calculated $\left(\Delta\right.$ dynes $\left./ \mathrm{cm}^{2}\right)$.

\section{Cell migration assay}

This cell migration assay was derived from the method described by Varani and Ward (1978) and adapted from that of Kiernan and ffrenchConstant (1993). A549 cells were resuspended at $40 \times 10^{6}$ cells $/ \mathrm{ml}$ in culture medium containing 10\% FCS and $0.3 \%$ agarose and maintained at $37^{\circ} \mathrm{C}$ to prevent setting of the agarose. $2 \mu \mathrm{l}$ drops of the cellular suspension were plated in the center of each well of a 24-well tissue culture plate. Wells were precoated with various concentrations of type I collagen (from 0 to $5 \mu \mathrm{g} / \mathrm{cm}^{2}$ ). The preparation was placed at $4^{\circ} \mathrm{C}$ for 15 minutes to allow the agarose to gel. Then, $0.5 \mathrm{ml}$ of serum free medium was added to cover the drop. The preparation was incubated at $37^{\circ} \mathrm{C}$ in $5 \% \mathrm{CO}_{2}-95 \%$ air for 24 hours. Samples were fixed and stained with Diff Quick kit (Dade). Photographs were then taken. In some cases, actin-staining with rhodaminated-phalloidin was done and cells were observed by confocal microscopy.

\section{Staining of F-actin with fluorescent phallotoxin and confocal microscopy}

Small round glass coverslides were placed in Petri dishes and coated with type I collagen at various concentrations, from 0 to $5 \mu \mathrm{g} / \mathrm{cm}^{2}$. Agarose drops were plated on the precoated glass coverslides (as described in the cell migration assay), placed in Petri dishes and incubated for 24 hours. At the end of this incubation Petri dishes were rinsed twice with warm cytoskeleton (CSK) buffer, $50 \mathrm{mM} \mathrm{NaCl}, 300$ $\mathrm{mM}$ sucrose, $3 \mathrm{mM} \mathrm{MgCl} 2,10 \mathrm{mM}$ Pipes, $\mathrm{pH}$ 6.8, which maintains the integrity of the CSK, as previously described (Burr et al., 1980). Cells were then fixed in methanol at $-20^{\circ} \mathrm{C}$ for 6 minutes, the methanol was removed and the samples were rinsed twice with CSK buffer. $1.5 \mu \mathrm{M}$ rhodaminated phalloidin were dissolved in CSK buffer and added to each sample for 30 minutes in the dark and under a humid chamber at room temperature. Coverslides were rinsed for 5 minutes twice with CSK buffer, the last rinse with $\mathrm{ddH}_{2} \mathrm{O}$. The coverslides were mounted on a slide with the cell side down in Vectashield mounting medium (VECTOR Laboratories, CA, USA).

Samples were stored at $4^{\circ} \mathrm{C}$ overnight before observation by laser confocal microscopy using an LSM 410 invert microscope (Zeiss, Rueil-Malmaison, France). The latter has two internal helium-neon lasers and one external argon ion laser. Image processing was performed using LSM 410 software. Fields of cells were randomly selected, brought into focus using a $\times 63 / 1.25$ numeric aperture Plan
Neofluor objective under transmitted light bright field conditions and briefly examined. A cross sectional image was recorded under confocal conditions and used to establish a plane of focus above the glass surface. Optical sections were recorded every $0.5 \mu \mathrm{m}$ to reveal intracellular fluorescence.

\section{In vitro wound healing assay}

The in vitro wound healing assay was carried out as previously described (Kheradmand et al., 1994; Matthay et al., 1993). Freshly isolated rat alveolar epithelial cells were seeded on 24-well tissue culture dishes $\left(10^{6}\right.$ cells/well) coated with type I collagen $\left(5 \mu \mathrm{g} / \mathrm{cm}^{2}\right)$. When confluence was reached, cell monolayers were incubated for 12 hours in serum free medium. The monolayers were then gently scratched with a pipette tip and extensively rinsed with medium to remove all cellular debris. The area of denuded surface was quantified over 24 hours with regular time intervals as describe before. The cells were placed on an inverted microscope (Zeiss, Rueil-Malmaison, France), and an image was obtained with the use of a charge-coupled device camera (C2400; NEC; Hawthorn, CA) connected to the microscope. The image was subsequently captured by an imageanalyzing frame-grabber card (LG-3 scientific Frame Grabber; Scion, Frederck, MD) and captured by an image analysis software (NIH Image 1.55). Closure of the wound was expressed as a ratio between the surface of the wound after a 23 hour incubation and the surface of the initial wound.

\section{Effect of collagenases on cell adhesion, cell migration, cell stiffness and on in vitro wound healing}

The effect of collagenases on cell adhesion, migration, stiffness or wound healing was tested by adding exogenous recombinant proMMP-1 or pro-MMP-13. The molar ratio of type I collagen to each collagenase was 20:1 otherwise specified.

The effect of collagenases on cell adhesion was tested by plating cells in DMEM containing collagenase during the 1 hour attachment period. The effect of collagenases on cell stiffness was tested by plating cells in DMEM containing collagenase 24 hours before magnetocytometry measurement. Two different concentrations of proMMPs were tested, $50 \mathrm{ng} / \mathrm{ml}$ and $250 \mathrm{ng} / \mathrm{ml}$. For the cell migration assay, the enzyme was added at the beginning of the 24 hour incubation period. For the in vitro wound healing assay, the collagenase was added in serum free medium just after the wound was made and over the 24 hour wound healing period. Control wells which included both wound healing in serum free medium (negative controls) or in $10 \%$ FCS containing medium (positive controls), were always done in parallel.

To test whether the effect of collagenases was due to collagen cleavage, cell migration, cell adhesion, cell stiffness and wound healing were also estimated under various conditions, either (i) in the presence of pro-MMP-1 and its inhibitor, either TIMP-1 (molar ratio between MMP-1:TIMP-1, 1:1) or BB-3103 (1 $\mu \mathrm{M})$, (ii) in the presence of activated MMP-1, or (iii) by performing the assay on type I collagen which had been incubated with MMP-1 prior to coating.

\section{Statistical analysis}

Statistical analysis was done by analysis of the variance to analyze differences among more than one group; if the ANOVA was significant further comparisons were done by Student's $t$-test. Differences between two groups were tested by Student's $t$-test.

\section{RESULTS}

\section{Cell attachment assay}

In preliminary studies, we determined the minimum time necessary for cell adhesion to occur on collagen. We also determined that the relationship between absorbance at $650 \mathrm{~nm}$ 


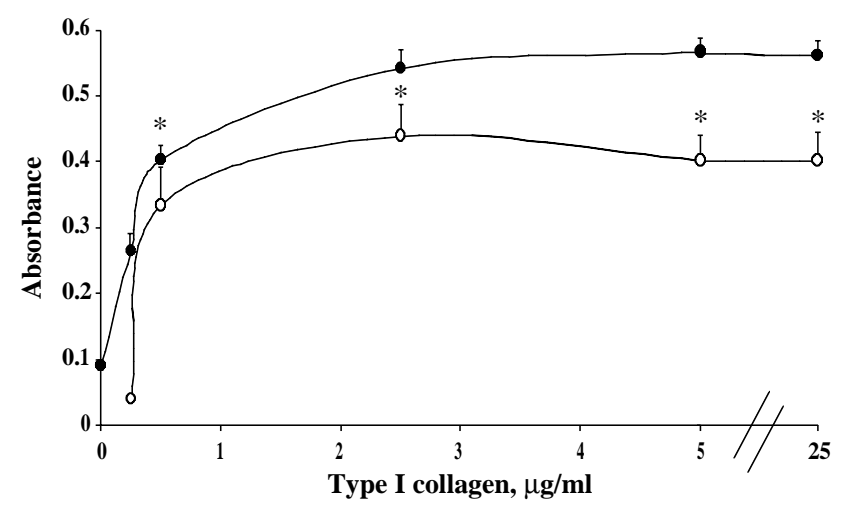

Fig. 1. Alveolar epithelial cell attachment to type I collagen. 96-well culture plates were coated with various concentrations of type I collagen. A549 cells were allowed to attach for 1 hour, fixed and stained as described in Materials and Methods. Absorbance at 650 $\mathrm{nm}$ ( $y$ axis) is presented against concentrations of type I collagen $(\mu \mathrm{g} / \mathrm{ml}, x$ axis) used to coat culture wells. A549 cell adhesion to collagen increased between 0 and $5 \mu \mathrm{g} / \mathrm{ml}$ collagen ( $)$ and then reached a plateau. Addition of exogenous pro-MMP-1 at a molar ratio of 20:1 (collagen:pro-MMP-1) caused a decrease in cell attachment $(\bigcirc)$. Data are mean \pm standard error. $* P<0.05$.

and the number of adherent cells was linear. We subsequently chose to plate $50 \times 10^{3}$ cells/well and incubate the cells for 1 hour to allow cell adhesion on coated plates.

A549 cells attached to collagen I with a dose-dependent relationship (Fig. 1). Addition of exogenous pro-MMP-1 at a molar ratio of 20:1 (collagen:pro-MMP-1) caused a decrease in cell attachment (Figs 1,2). A similar decrease was observed when active MMP-1 instead of pro-MMP-1 was used (Fig. 2A). Addition of pro-MMP-13 also caused a decrease in cell attachment (data not shown). The collagenase-induced decrease in cell adhesion was reversed by exogenous MMP inhibitor, TIMP-1, but only partially reversed by BB-3103 (Fig. 2B). Addition of inhibitors alone did not affect cell attachment (data not shown).

To confirm that the decrease in cell attachment to collagen in the presence of collagenases was due to collagen cleavage, we compared cell attachment to intact collagen versus MMP1-cleaved collagen. The number of adherent cells to cleaved collagen was smaller than on intact collagen (Fig. 2C).

\section{Cytoskeleton stiffness measured by magnetocytometry}

We examined whether exogenous pro-MMP-1 or pro-MMP-13 could modify CSK stiffness of cells plated over collagen using magnetocytometry. Pro-MMP-1 decreased the CSK stiffness compared to CSK stiffness of cells grown in serum-free medium (Fig. 3A). Similar results were obtained with proMMP-13 (Fig. 3C). Two concentrations of pro-MMPs were tested and were found to have a dose-dependent effect on CSK stiffness (Fig. 3A-C).

Addition of cytochalasin $\mathrm{D}$ to alveolar epithelial cells grown on type I collagen induced a decrease in CSK stiffness (Fig. 3B-D) which can be expressed as the difference between the stiffness before and after cyto D. This difference was smaller when cells had been grown for the previous 24 hours in the presence of either exogenous pro-MMP-1 or pro-MMP-13, in
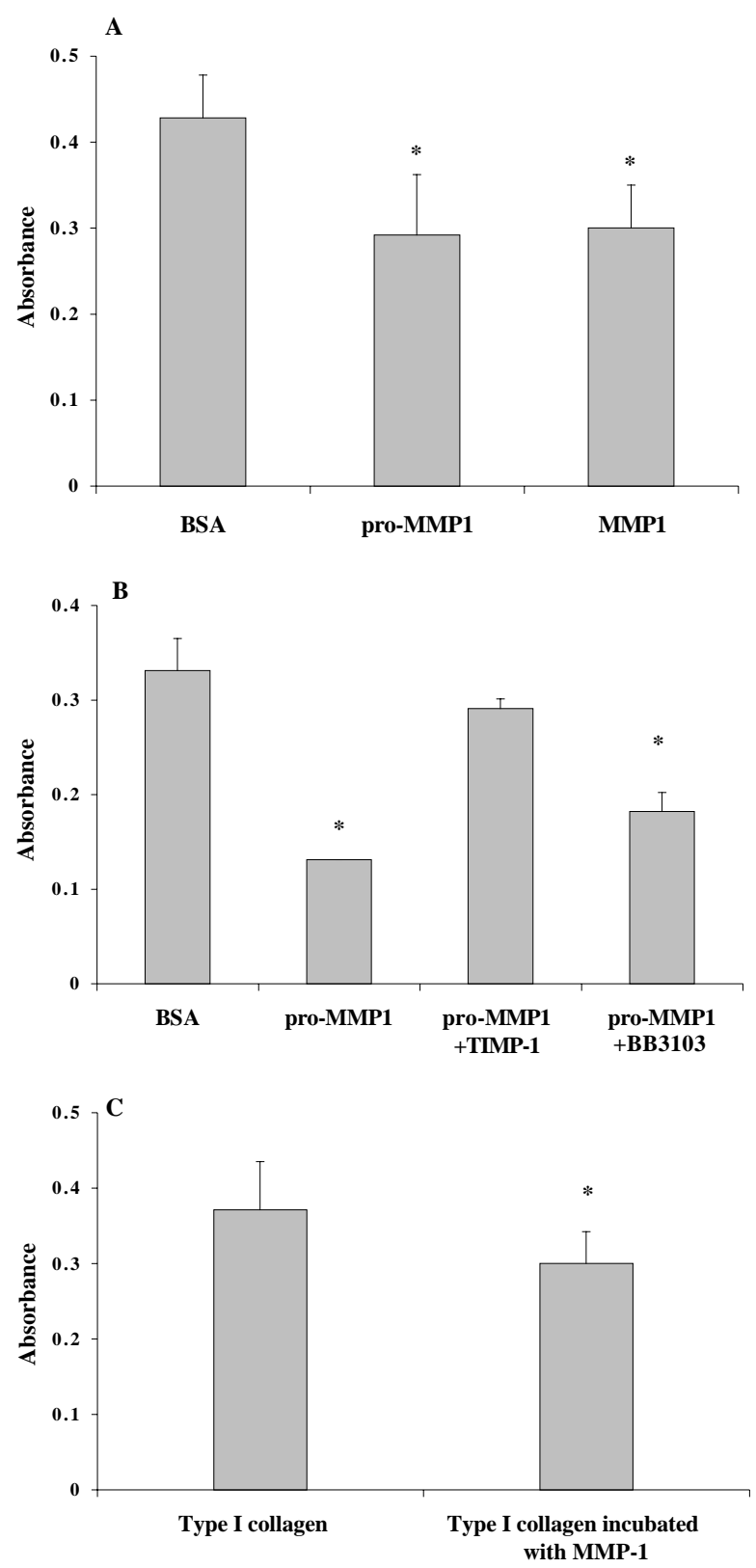

Fig. 2. Effect of exogenous collagenase and of MMP inhibitor on A549 alveolar epithelial cell attachment to type I collagen. $5 \mu \mathrm{g} / \mathrm{ml}$ of type I collagen were used to coat 96-well culture plates. A549 cells were allowed to attach to collagen for 1 hour, either in serum free medium alone, or in culture medium containing exogenous collagenase and/or MMP inhibitors, BB-3103 or TIMP-1. Unattached cells were flicked off and bound cells were fixed and stained. The absorbance $(A)$ of released dye was read at $650 \mathrm{~nm}$ on a multiwell plate reader. Data are mean \pm standard error. (A) Addition of exogenous pro-MMP-1 at a molar ratio of 20:1 (collagen: pro-MMP-1) caused a decrease in cell attachment (pro-MMP1) compared to control (BSA). A similar decrease was observed when active MMP-1 (MMP1) instead of proMMP-1 was used. (B) MMP-1-induced decrease in cell adhesion was abolished by MMP inhibitor, TIMP-1 (pMMP1 + TIMP1), and partially reversed by BB-3103 (pMMP1 + BB 3103). $* P<0.01$, versus control (BSA). (C) A549 alveolar epithelial cell attachment to intact versus cleaved type I collagen. 96-well culture plates were coated with $5 \mu \mathrm{g} / \mathrm{ml}$ of either intact fibrillar type I collagen or type I collagen cleaved by MMP-1 prior to coating. Number of adherent cells to cleaved collagen was less than on intact collagen. $* P<0.05$. 
a dose dependent manner (Fig. 3B-D), indicating that CSK basal tone was modified by MMPs collagenases.

\section{Cell migration}

A549 cells migrated out from the agarose drop when it was plated on collagen at a concentration of 0.25 or $0.5 \mu \mathrm{g} / \mathrm{cm}^{2}$. Higher concentrations of collagen $\left(1\right.$ and $\left.5 \mu \mathrm{g} / \mathrm{cm}^{2}\right)$ inhibited
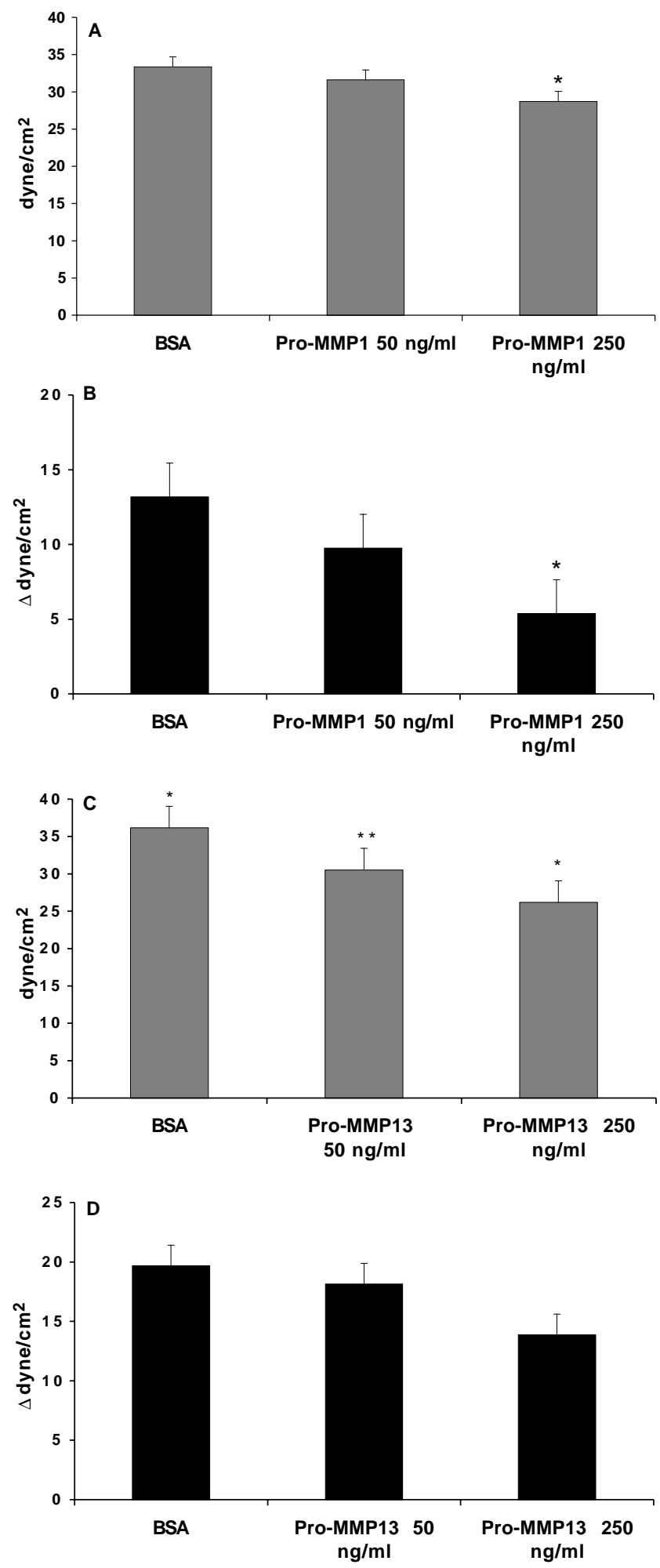

cell migration (Fig. 4A). As a positive control, we checked in parallel that A549 cells were able to migrate when plated on another substrate, such as fibronectin $\left(5 \mu \mathrm{g} / \mathrm{cm}^{2}\right.$, data not shown).

By contrast, cell migration on $1 \mu \mathrm{g} / \mathrm{cm}^{2}$ type I collagen was induced when exogenous pro-MMP-1 was added, at a molar ratio of 20:1 (Fig. 4B). A similar result was obtained by addition of pro-MMP-13 (Fig. 4C). Similarly, cell migration was also induced when the agarose drop was plated over MMP 1-cleaved collagen (1 $\mu \mathrm{g} / \mathrm{cm}^{2}$, Fig. 4D).

Staining of the actin cytoskeleton and observation under confocal microscopy demonstrated that cell migration was associated with a migratory phenotype. The spreading cells showed actin stress fibers at their basal face (Fig. 5B).

\section{In vitro wound healing assay}

The influence of collagenases on motility of alveolar cells on type I collagen was quantified by measuring the closure of a wound in confluent monolayers. Over 24 hours after wounding, exogenous pro-MMP-1 or pro-MMP-13 induced more rapid closure of the wound (Figs 6A, 7) compared with serum free conditions (Figs 6C, 7). The effects of pro-MMPs were dosedependent. MMPs inhibitors, either BB-3103 or TIMP-2, abolished the effect of both exogenous collagenases; BB-3103 alone gave the same result as the serum free condition (Fig. 7).

\section{DISCUSSION}

Acute lung injury causes loss of alveolar epithelial type I pneumocytes and damages the basement membrane (Mac Gowan, 1992). Successful repair of the alveolo-capillary barrier requires re-epithelialization of the alveolar surface. The repair involves migration and proliferation of type II pneumocytes which replace damaged type I pneumocytes (Adamson and Bowden, 1974; Lwebuga-Mukasa et al., 1986). Alveolar type II pneumocytes migrate over a provisional

Fig. 3. Cytoskeleton (CSK) stiffness assessed by magnetocytometry. A549 cells were plated at the density of $50 \times 10^{3} /$ well and incubated for 24 hours. RGD-coated ferromagnetic microbeads were then added to the cells. Wells were placed into the magnetic twisting cytometer. A brief 1500 gauss magnetic pulse was applied to magnetize all surface bound beads in a unique horizontal direction, then a magnetic torque was generated by applying an orthogonal homogenous magnetic field (42 gauss). Associated changes in angular strain of the beads were measured by an on-line magnetocytometer. CSK stiffness was defined as the ratio of shear stress to angular strain. Data are mean $\left(\right.$ dyne $\left./ \mathrm{cm}^{2}\right) \pm$ standard error of triplicates from 3 separate experiments. $* P<0.05$ versus BSA, $* * P<0.001$ versus BSA. (A and C) The effect of either exogenous pro-MMP-1 (A) or exogenous pro-MMP-13 (C) added at the beginning of the 24 hour-incubation period, on the CSK stiffness. In the presence of pro-MMPs, the CSK stiffness was decreased compared to control grown in serum-free medium (BSA). Two concentrations of pro-MMPs were tested $(250 \mathrm{ng} / \mathrm{ml}$ and $50 \mathrm{ng} / \mathrm{ml})$. (B and D) The difference between CSK stiffness before and after cyto $D$ in the absence or in the presence of either 50 or $250 \mathrm{ng} / \mathrm{ml}$ pro-MMP-1, pro-MMP13. The decrease in CSK stiffness induced by cytochalasin D was less in the presence of exogenous pro-MMPs than when cyto D was added to cells grown without MMPs, indicating differences in the basal tone of CSK. 

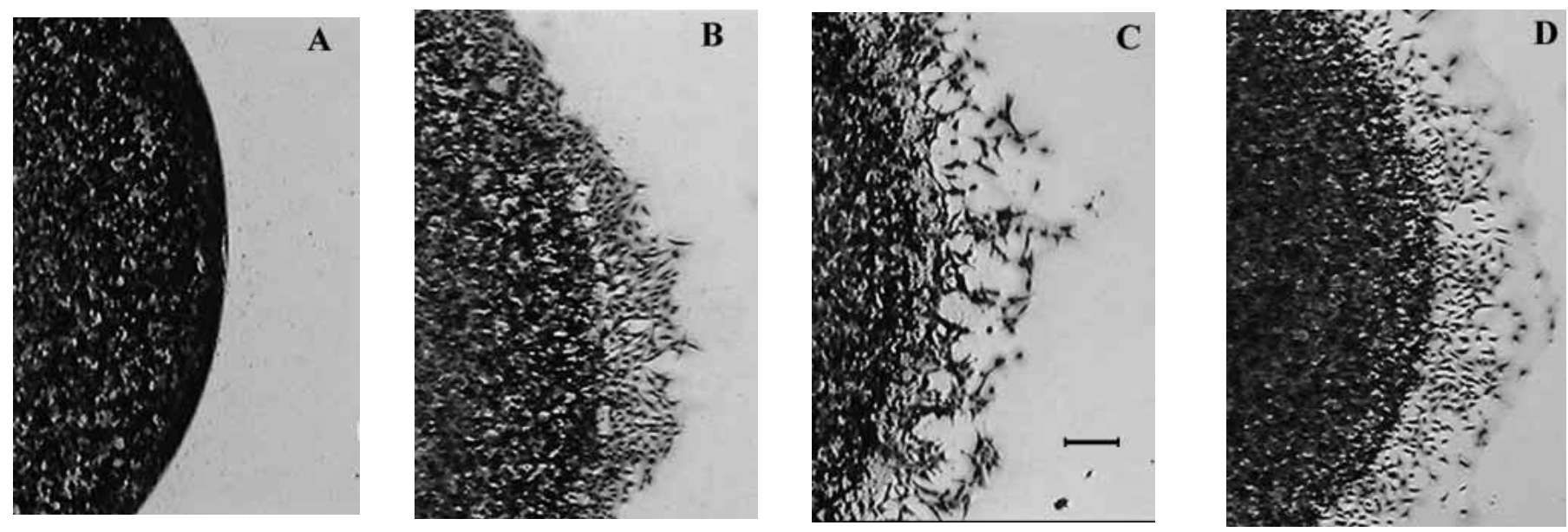

Fig. 4. A549 alveolar epithelial cells motility over type I collagen. Cells were suspended at $40 \times 10^{6}$ cells/ml in culture medium containing agarose. Drops of the cell suspension were plated in the center of 24 -well tissue culture plate coated with $1 \mu \mathrm{g} / \mathrm{cm}^{2}$ of type I collagen. The preparation was incubated at $37^{\circ} \mathrm{C}$ in a $5 \% \mathrm{CO}_{2}-95 \%$ air atmosphere for 24 hours to allow cell migration, and cells were stained with Diffquick ${ }^{\circledR}$. Photographs were taken under a microscope. Bar, $50 \mu \mathrm{m}$. (A) No migration occurred when the agarose drop was placed on type I collagen at concentration of $1 \mu \mathrm{g} / \mathrm{cm}^{2}$. (B) Cell migration on $1 \mu \mathrm{g} / \mathrm{cm}^{2}$ type I collagen was induced by adding pro-MMP-1. A similar result was obtained by adding pro-MMP-13 (C), and by plating the agarose drop on type I collagen which had been cleaved by MMP-1 prior to coating (D).

wound matrix composed essentially of fibrinogen, fibronectin and fibrillar collagens. The repair is achieved by replacement of the provisional matrix by normal basement membrane, and by differentiation of type II pneumocytes to type I pneumocytes. The aim of the present study was: (i) first to evaluate cell adhesion and migration as well as stiffness of alveolar epithelial cell cytoskeleton (CSK), over a matrix similar to the provisional matrix encountered in vivo, namely type I collagen; (ii) second to study modulation of these processes by two MMP collagenases, MMP-1 and MMP-13, in vitro. To obtain further insight into mechanisms of alveolar epithelial repair, we also tested the effect of MMP collagenases on an in vitro wound healing assay using primary cultures of alveolar epithelial rat pneumocytes. The present study clearly indicates that MMP collagenases, both MMP-1 and MMP-13, decreased alveolar cell CSK stiffness and cell adhesion to type I collagen, increased cell migration, and accelerated the closure of an in vitro wound. The use of MMP-inhibitors and of MMP1 cleaved-type I collagen suggests that the effects of MMP-1 and -13 were due to collagen cleavage.

Fig. 5. Staining of the F-actin cytoskeleton and observation by confocal microscopy. Small round glass coverslides were placed in Petri dishes and coated with type I collagen at $1 \mu \mathrm{g} / \mathrm{cm}^{2}$. Cells were suspended at $40 \times 10^{6}$ cells $/ \mathrm{ml}$ in culture medium containing agarose. Drops of the cell suspension were plated in the glass coverslip. After 15 minutes, the gelling process of the agarose at $4^{\circ} \mathrm{C}, 0.5 \mathrm{ml}$ of serum free medium were added to cover the drops. The preparation incubated at $37^{\circ} \mathrm{C}$ in a $5 \% \mathrm{CO}_{2}-95 \%$ air atmosphere for 24 hours to allow cell migration. At the end of this incubation, cells were fixed in methanol and $1.5 \mu \mathrm{M}$ rhodaminated phalloïdin were added. The coverslips were mounted and observed by confocal microscopy. Bar, $25 \mu \mathrm{m}$. (A) Over the 24 hours-incubation period, no migration occurred on type I collagen when the preparation incubated in serum free medium alone, and the cells retained a round shape. By contrast, addition of pro-MMP- 1 during the 24 hours-incubation period induced cell migration (B). The spreading cells spread and showed actin stress fibers at their basal face.
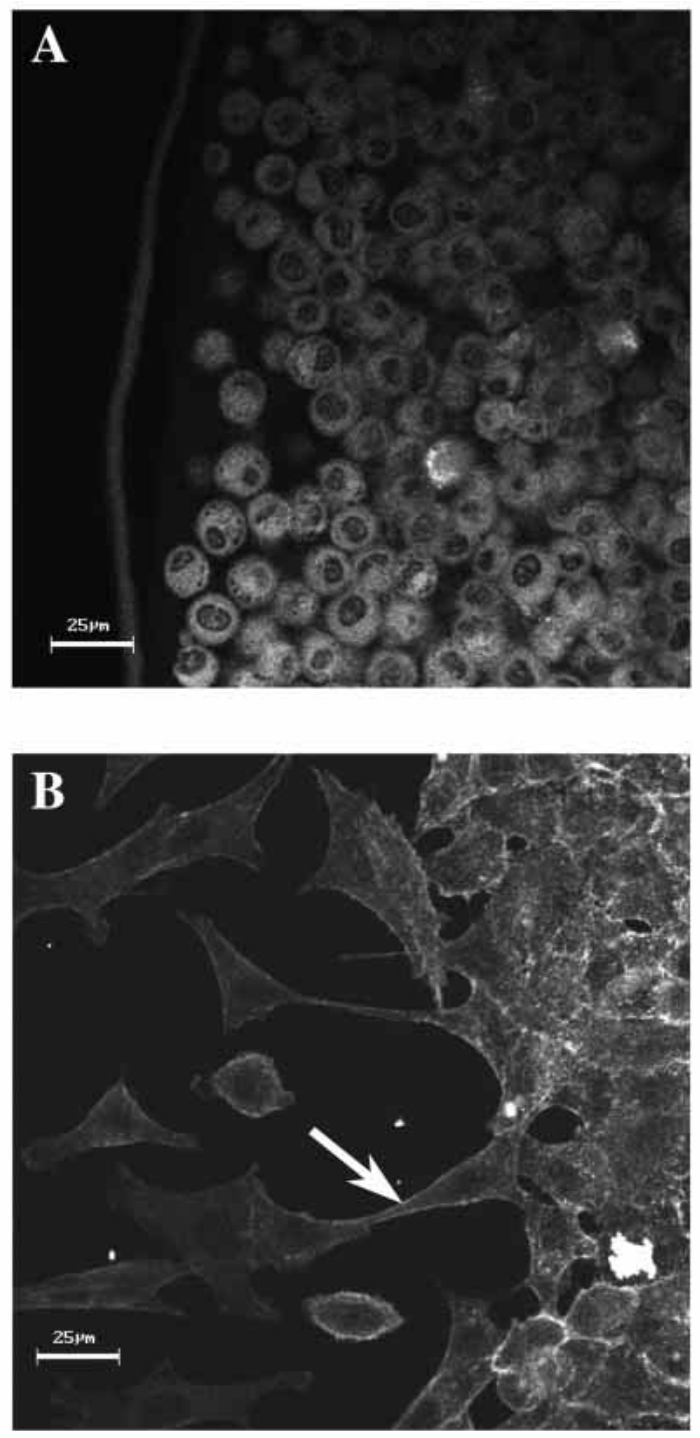

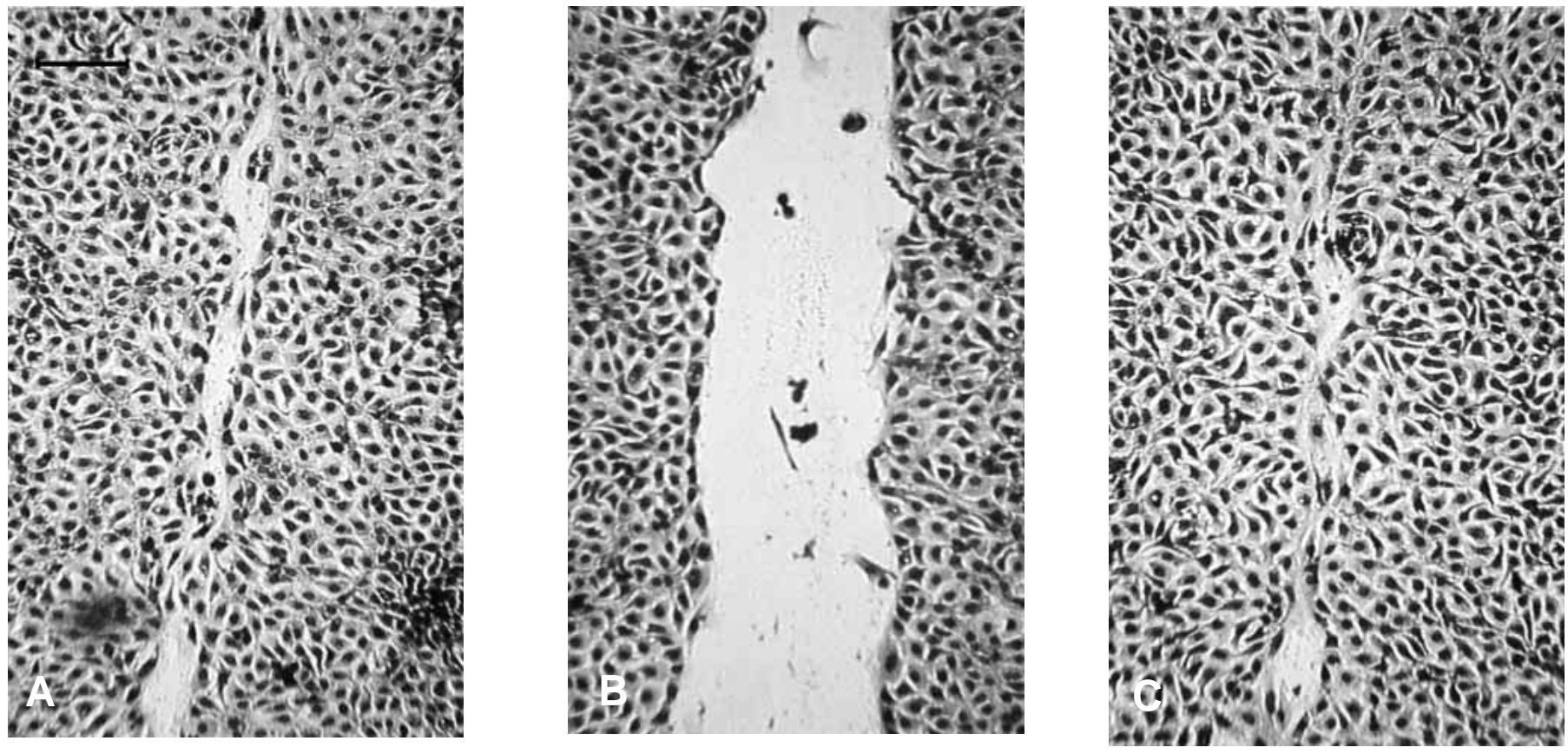

Fig. 6. In vitro wound healing assay. Freshly isolated rat type II pneumocytes were seeded on 24 -well plates coated with $5 \mu \mathrm{g} / \mathrm{cm}^{2}$ type I collagen. When confluence was reached, cell monolayers were then gently scratched with a pipette tip and extensively rinsed with medium to remove all cellular debris. The closure of the wound was observed over a 24 hour period. The cells were placed under an inverted microscope and an image was obtained with the use of a charge-coupled device camera connected to the microscope. Bar, $100 \mu \mathrm{m}$. (A) Over 24 hours after wounding, $250 \mathrm{ng} / \mathrm{ml}$ pro-MMP-13 induced a twofold more rapid closure of the wound than compared with serum free conditions (B). (C) Wound closure with $10 \%$ FCS.

Alveolar epithelial cells adhered to type I collagen in a dosedependent manner, and exogenous pro-MMP-1 as well as exogenous pro-MMP-13 decreased cell adhesion. Several lines of evidence suggest that the decrease in cell adhesion was due to collagenolysis with activation of pro-collagenases during the experiment: (i) no further decrease was obtained by adding activated MMP-1; (ii) the greater decrease in cell adhesion was obtained with pro-MMP-13 compared to pro-MMP-1, also suggesting that activation of pro-collagenase was achieved during the attachment period since pro-MMP-13 can achieve auto-activation more efficiently than pro-MMP-1 (Knäuper et al., 1996a). Nevertheless, MMP-13 could interfere directly with cell adhesion through its interaction with membrane-type MMP (Knaüper et al., 1996b). Eventually, (i) results of cell adhesion performed on plastic coated with collagen pretreated with MMP-collagenases, which gave a further decrease in cell adhesion, and (ii) the partial inhibition of MMP-1-induced decrease in cell adhesion obtained with MMP inhibitor, TIMP1 , further demonstrated the importance of collagen-cleavage in the decrease in cell adhesion.

Modifications of the strength of linkages between cell and extracellular matrix by collagenases were further inferred from the measurement of CSK stiffness. Indeed, it has been previously shown that CSK stiffness, determined either by magnetocytometry (Lee et al., 1998; Wang and Ingber, 1994), or by optical trapping (Choquet et al., 1997), is directly proportional to the strength of cell-matrix interactions. Magnetocytometry is a relatively new technique which allows measurement of CSK stiffness by application of controlled mechanical stresses directly to cell-surface integrins, using
RGD-coated micro-beads. We found that CSK stiffness was reduced in the presence of either MMP-1 or MMP-13 in a dosedependent manner and that the cytochalasin D-induced decrease in CSK stiffness was inversely dependent on MMPs concentration. The latter result demonstrates that the basal CSK tone was lower in the presence of exogenous collagenases. Altogether, the magnetocytometry results suggest a collagenase induced-decrease in cell-matrix interactions, both quantitatively and qualitatively.

The collagenase-induced decrease in cell adhesion and modifications of cell-collagen interactions was similar to the results obtained by Messent et al. (1998) although with a different cell type. Loss of HT1080 cell adhesion to the 1/4-collagen fragment obtained specifically by MMP-collagenase cleavage was observed compared to the cell adhesion to intact type I collagen. Messent et al. demonstrated that this loss was due to a decrease in binding of $\alpha 2 \beta 1$ integrin to the 3/4 and 1/4-fragments. It has been suggested that denaturation of collagen following collagenase cleavage causes unfolding of the collagen triple helix to reveal cryptic RGD sequence (Davis, 1992; Messent et al., 1998). Cell interactions with denatured collagen has been postulated to be mediated by $\alpha v \beta 3$ integrin rather than $\alpha 2 \beta 1$ (Montgomery et al., 1994), both $\alpha v \beta 3$ and $\alpha 2 \beta 1$ being expressed by alveolar epithelial cells in vitro (Kim et al., 1996, 1997). Differences in cell adhesive strength mediated either by $\alpha v \beta 3$ or by $\alpha 2 \beta 1$ integrins could explain the differences observed regarding cell adhesion on intact versus cleaved collagen both in the present and in previous studies (Messent et al., 1998).

Cell migration to, or through, extracellular matrix components has already been studied, including migration of 

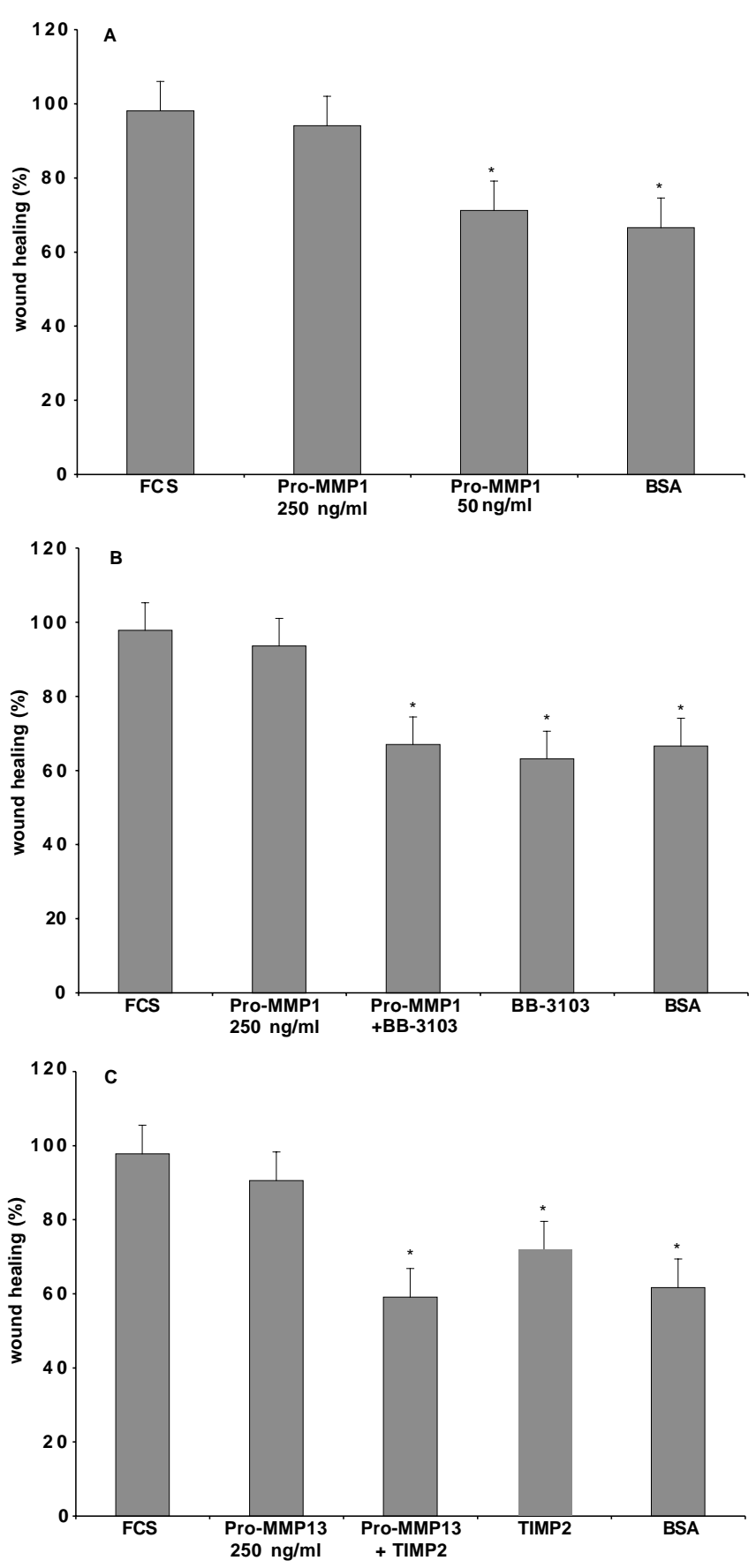

alveolar epithelial cells (Kim et al., 1997; Lesur et al., 1996). Most recently, experiments have been done using Boyden chambers. For the purpose of this study we chose a different model, namely migration out from an agarose drop. Indeed, in the latter model, the migration occurs over the extracellular matrix rather than through it. Hence, the method seemed more relevant to alveolar cell migration which occurs during repair. We found that type I collagen induced cell migration below 1 $\mu \mathrm{g} / \mathrm{cm}^{2}$, but that higher concentrations inhibited migration. These results were quite similar to those of Lesur et al. (1996) who found a bell-shape dose-response curve for alveolar cell locomotion to type I collagen. When we tested migration over
Fig. 7. Effect of exogenous collagenase on the in vitro wound healing. Freshly isolated rat type II pneumocytes were seeded on 24well plates coated with $5 \mu \mathrm{g} / \mathrm{cm}^{2}$ type I collagen. When confluence was reached, cell monolayers were gently scratched with a pipette tip. The closure of the wound was observed over a 24 hour period. The cells were placed under an inverted microscope and an image was obtained with the use of a charge-coupled device camera connected to the microscope. The picture was subsequently grabbed by an image-analyzing frame-grabber card and captured by an image analysis software which allowed a quantification of the surface of the wounded area. The closure of the wound is measured as a $\%$ of the initial surface. Data are mean \pm standard error of triplicates, $* P<10^{-3}$ compared to FCS. (A) The closure of the wound (\%) at 23 hours. Two different concentrations of pro-MMP-1 were used: 50 and 250 $\mathrm{ng} / \mathrm{ml} .250 \mathrm{ng} / \mathrm{ml}$ of pro-MMP-1 induced a better closure of the wound compared with serum free condition (BSA). The pro-MMP-1 induced-wound closure was similar to that obtained by adding $10 \%$ FCS (FCS). Data are mean \pm standard error of triplicates from three separate experiments. (B) Closure of the wound (\%) at 23 hours in the presence of pro-MMP-1 $(250 \mathrm{ng} / \mathrm{ml})$, or in the presence of both pro-MMP-1 and MMP inhibitor BB-3103, or in the presence of BB3103 alone, compared to positive controls (in the presence of FCS) and to negative controls (BSA). $250 \mathrm{ng} / \mathrm{ml}$ pro-MMP-1 induced an almost complete wound closure within 23 hours. The effect of exogenous pro-MMP-1 on wound closure was abolished by the MMP inhibitor BB3103. (C) Closure of the wound (\%) at 24 hours in the presence of pro-MMP-13 $(250 \mathrm{ng} / \mathrm{ml})$, or in the presence of both pro-MMP-13 and MMP inhibitor TIMP-2, or in the presence of TIMP-2 alone, compared to positive controls (in the presence of FCS) and to negative controls (BSA).

an inhibiting concentration of type I collagen such as $1 \mu \mathrm{g} / \mathrm{cm}^{2}$, addition of exogenous collagenases restored the migration. Similar effects on cell migration were observed when using 1 $\mu \mathrm{g} / \mathrm{cm}^{2}$ of MMP 1-cleaved collagen suggesting that MMP-1 promoted cell migration by collagen cleavage. Those results are quite similar to those of Giannelli et al. (1997) who found induction of breast epithelial cell migration by MMP-2 cleavage of laminin-5. Altogether, these results suggest that structural changes in the extracellular matrix are necessary for cell locomotion to occur. Those structural changes could influence cell function by modifying cell-matrix interactions and/or modifying the mechanical environment of adherent cells.

A close relationship exists between cell adhesion and cell migration. Both theory and experimental works suggest that an intermediate level of attachment strength produces maximal migration rates (Di Milla et al., 1991, 1993). It is likely that migration follows a bell-shape curve as a function of adhesion: initially, cell migration increases with cell adhesion, maximal migration rate is then obtained for an intermediate level of adhesion strength, and then migration decreases as cell adhesion increases. Our results suggest that, under these in vitro conditions, alveolar epithelial cell interactions with collagen are such that we are in the second half of the curve, where migration decreases when cell adhesion increases. MMP-collagenases, via cleavage of collagen, decreased cell adhesion to collagen, thereby explaining why cell migration over collagen is facilitated. Nevertheless, the relationship between cell adhesion and migration is probably even more complex given the asymmetry between the leading and trailing edges of the cell (Huttenlocher et al., 1995). 
The use of the in vitro wound assay on primary culture of alveolar epithelial cells has allowed us to further test the role of MMP-1 and MMP-13 in alveolar repair. A role for MMPs in repair has been previously hypothesized, but the underlying molecular mechanisms are not yet fully understood. MMP-1 is expressed by keratinocytes at the edges of the wounded skin in vivo (Saarialho-Kere et al., 1994). In vitro, expression of MMP-1 by keratinocytes is induced by culture on type I collagen and locomoting keratinocytes are followed by a trail of degraded collagen (Pilcher et al., 1997). In terms of lung epithelial repair, Buisson et al. (1996a,b) reported that both MMP-9 (gelatinase B) and MMP-3 (stromelysin-1), are expressed in vitro by healing bronchial epithelial cells, and that gelatinase B plays an active role in the repair process, since the latter is inhibited by blocking antibodies directed to gelatinase B. MMP could play a role in tissue repair by several mechanisms, first by remodeling extracellular matrix, but also by releasing growth factors such as VEGF, TGF $\beta$ or bFGF, from the proteoglycans where they are stored (Dallas et al., 1995; Taipale and Keski-Oja, 1997), or by cleaving some growth factor receptors, such as FGF receptor or IGF-BP3 (Fowlkes et al., 1994; Levi et al., 1996). MMPs could also facilitate de-adhesion during the cell migration process, as suggested by our current results. The present study emphasizes the importance of matrix degrading enzymes, MMPs, in controlling cell-matrix interactions, and their key role in fundamental cell process such as tissue repair.

We thank Dr Chrystelle Garat and Bonnie Oliver for having shared their experience in alveolar wound healing, Oscar Osario for his technical assistance in animals surgery and Antoine Mary for his technical assistance in magnetocytometric measurements. This study has been supported by Institut National de la Santé et de la Recherche Médicale (INSERM, France, contrat no. 4M106C Intercommission no. 1), by Legs Poix (Chancellerie des Universités, Paris, France), by Medical Research Council (UK), and by NIH grant no. HL51854 (USA).

\section{REFERENCES}

Adamson, I. Y. R. and Bowden, D. H. (1974). The type II cells as progenitors of alveolar epithelial regeneration. A cytodynamic study in mice following exposure to oxygen. Lab. Invest. 30, 35-42.

Anderson, W. R. and Thielen, K. (1992). Correlative study of ARDS by light, scanning and transmission electron microscopy. Ultrastruct. Pathol. 16, 615-628.

Aumailley, M. and Timpl, R. (1986). Attachment of cells to basement membrane collagen type IV. J. Cell Biol.103, 1569-1575.

Buisson, A., Gilles, C., Polette, M., Zahm, J., Birembaut, P. and Tournier, J. (1996a). Wound repair-induced expression of a stromelysin is associated with the acquisition of a mesenchymal phenotype in human respiratory epithelial cells. Lab. Invest. 74, 658-69.

Buisson, A., Zahm, J., Polette, M., Pierrot, D., Bellon, G., Puchelle, E., Birembaut, P. and Tournier, J. (1996b). Gelatinase B is involved in the in vitro wound repair of human respiratory epithelium. J. Cell Physiol.166, 413-26.

Burr, J. G., Dreyffuss, G., Penman, S. and Buchanan, J. M. (1980). Proc. Nat. Acad. Sci. USA 88, 7849-7853.

Choquet, D., Feisenfeld, D. P. and Sheetz, M. P. (1997). Extracellular matrix rigidity causes strengthening of integrin-cytoskeleton linkages. Cell 88, 3948.

Clerici, C., Friedlander, G. and Amiel, C. (1992). Impairment of sodiumcoupled uptakes by hydrogen peroxide in alveolar type II cells: protective effects of d- $\alpha$-tocopherol. Am. J. Physiol. 262 (Lung Cell Mol. Physiol. 6), L542-L548.
Dallas, S. L., Miyazono, K., Skerry, T. M., Mundy, G. R. and Bonewald, L. F. (1995). Dual role for the latent transforming growth factor- $\beta$ in the extracellular matrix and as a structural matrix protein. J. Cell Biol.131, 539549

Davis, G. E. (1992). Affinity of integrins for damaged extracellular matrix: $\alpha \mathrm{v} \beta 3$ binds to denatured collagen type I through RGD sites. Biochem. Biophys. Res. Commun. 182, 1025-1031.

Di Milla, P. A., Barbee, K. and Lauffenburger, D. A. (1991). Mathematical model for the effects of adhesion and migration on cell migration speed. Biophys. J. 60, 15-37.

Di Milla, P. A., Stone, J. A., Quinn, J. A., Albelda, S. M. and Lauffenburger, D. A. (1993). Maximal migration of human smooth muscle cells on fibronectin and type IV collagen occurs at an intermediate attachment strength. J. Cell Biol.122, 729-737.

d'Ortho, M.-P., Clerici, C., Yao, P. M., Delacourt, C., Delclaux, C., FrancoMontoya, M.-L., Harf, A. and Lafuma, C. (1997a). Alveolar epithelial cells in vitro produce gelatinases and tissue inhibitor of metalloproteinase2. Am. J. Physiol. 273 (Lung Cell Mol. Physiol. 17), L663-L675.

d'Ortho, M.-P., Will, H., Atkinson, S., Butler, G., Messent, A., Gavrilovic, J., Zardi, L. and Murphy, G. (1997b). Membrane-type metalloproteinases 1 and 2 (MT1-MMP and MT2-MMP) exhibit a broad spectrum proteolytic capacity comparable to many matrix metalloproteinases. Eur. J. Biochem. 250, 751-757.

Fowlkes, J., Enghild, J., Suzuki, K. and Nagase, H. (1994). Matrix metalloproteinases degrade insulin-like growth factor-binding protein-3 in dermal fibroblast cultures. J. Biol. Chem. 269, 25742-6.

Freije, J., Diez-Itza, I., Balbin, M., Sanchez, L., Blasco, R., Tolivia, J. and Lopez-Otin, C. (1994). Molecular cloning and expression of collagenase3 , a novel human matrix metalloproteinase produced by breast carcinomas. J. Biol. Chem. 269, 16766-73.

Giannelli, G., Falk-Marzillier, J., Schiraldi, O., Stetler-Stevenson, W. G. and Quaranta, V. (1997). Induction of cell migration by MMP-2 cleavage of laminin-5. Science 277, 225-228.

Huttenlocher, A., Sandborg, R. R. and Forwitz, A. F. (1995). Adhesion in cell migration. Curr. Opin. Cell Biol. 7, 697-706.

Ingber, D. (1991). Integrins as mechanochemical transducers. Curr. Opin. Cell Biol. 841-848.

Kheradmand, F., Folkesson, H. G., Shum, L., Derynk, R., Pytela, R. and Matthay, M. A. (1994). TGF $\alpha$ enhances alveolar epithelial cell repair in a new in vitro model. Am. J. Physiol. 267 (Lung Cell Mol. Physiol. 11), L728L738.

Kiernan, B. W. and ffrench-Constant, C. (1993). Oligodendrocyte precursor (O-2A pporgenitor cells) migration. A model system for the study of cell migration in the developing central nervous system. Development Suppl, 219-225.

Kim, H. J., Ingbar, D. H. and Henke, C. A. (1996). Integrin mediation of type II cell adherence to provisional matrix proteins. Am. J. Physiol. (Lung Cell Mol. Physiol. 5) 271, L277-L286.

Kim, H. J., Henke, C. A., Savik, S. K. and Ingbar, D. H. (1997). Integrin mediation of alveolar epithelial cell migration on fibronectin and type I collagen. Am. J. Physiol. (Lung Cell Mol. Physiol. 17) 273, L134-L141.

Knäuper, V., Lòpez-Otin, C., Smith, B., Knight, G. and Murphy, G. (1996a). Biochemical characterization of human collagenase-3. J. Biol. Chem. 271, 1544-1550

Knaüper, V., Smith, B., Stanton, H., Hembry, R. and Murphy, G. (1996b). Cellular mechanisms for human procollagenase-3 (MMP-13) activation. $J$. Biol. Chem. 271, 17124-17131.

Laurent, V., Planus, E., Mary, A. and Isabey, D. (1998). Mesure de la rigidite cellulaire par magnetocytometrie. Arch. Int. Physiol. Bioch. 106, 183.

Lee, K.-M., Tsai, K. Y., Wang, N. and Ingber, D. E. (1998). Extracellular matrix and pulmonary hypertension: control of vascular smooth muscle cells contractility. Am. J. Physiol. 274 (Heart Circ. Physiol. 43), H76-H82.

Lesur, O., Arsalane, K. and Lane, D. (1996). Lung alveolar epithelial cell migration in vitro: modulators and regulation processes. Am. J. Physiol. 270 (Lung Cell Mol. Physiol. 14), L311-L319.

Levi, E., Fridman, R., Miao, H., Ma, Y., Yayon, A. and Vlodavsky, I. (1996). Matrix metalloproteinase 2 releases active soluble ectodomain of fibroblast growth factor receptor 1. Proc. Nat. Acad. Sci. USA 93, 7069-74.

Lwebuga-Mukasa, J. S., Ingbar, D. H. and Madri, J. A. (1986). Repopulation of a human alveolar matrix by adult rat type II pneumocytes in vitro. Exp. Cell Res. 162, 423-435.

Mac Gowan, S. E. (1992). Extracellular matrix and the regulation of lung development and repair. FASEB J. 6, 2895-2904.

Matthay, M. A., Thiery, J.-P., Lafont, F., Stampfer, M. F. and Boyer, B. 
(1993). transient effect of epidermal growth factor on the motility of an immortalized mammary epithelial cell line. J. Cell Sci. 106, 869-878.

Messent, A. J., Tuckwell, D. S., Knäuper, V., Humphries, M. J., Murphy, G. and Gavrilovic, J. (1998). Effects of collagenase-cleavage of type I collagen on $\alpha 2 \beta 1$ integrin-mediated cell adhesion. J. Cell Sci. 111, 11271135.

Montgomery, A. M. P., Reisfeld, R. A. and Cheresh, D. A. (1994). Integrin $\alpha v \beta 3$ rescues melanoma cells from apoptosis in three-dimensional dermal collagen. Proc. Nat. Acad. Sci. USA 91, 8856-8860.

Murphy, G., Houbrechts, A., Cockett, M. I., Williamson, R. A., O'Shea, M. and Docherty, A. J. P. (1991). The N-terminal domain of tissue inhibitor of metalloproteinases retains metalloproteinase inhibitory activity. Biochemistry 30, 8097-8102.

Murphy, G., Allan, J. A., Willenbrock, F., Cockett, M. I., O'Connell, J. P. and Docherty, A. J. P. (1992). The role of the C-terminal domain in collagenase and stromelysin specificity. J. Biol. Chem. 267, 9612-9618.

Murphy, G. and Reynolds, J. J. (1993). Extracellular matrix degradation. In Connective Tissue and its Heritable Disorders. Molecular, Genetic, and Medical Aspects (ed. P. M. Royce and B. Steinmann), pp. 287-316. NewYork: Wiley-Liss.

Pardo, A., Selman, M., Ridge, K., Barrios, R. and Sznadjer, J. I. (1996). Increased expression of gelatinases and collagenase in rat lung exposed to 100\% oxygen. Am. J. Resp. Crit. Care Med. 154, 1067-1075.

Pardo, A., Ridge, K., Uhal, B., Sznadjer, J. I. and Selman, M. (1997). Lung alveolar epithelial cells synthesize interstitial collagenase and gelatinases A and B in vitro. Int. J. Biochem. Cell Biol. 29, 901-910.

Pilcher, B. K., Dumin, J. A., Sudbeck, B. D., Krane, S. M., Welgus, H. G. and Parks. (1997). The activity of collagenase-1 is required for keratinocyte migration on type I collagen matrix. J. Cell Biol.137, 1445-1457.

Saarialho-Kere, U., Penttland, A. P., Birkedaal-Hansen, H., Parks, C. W. and Welgus, H. G. (1994). Distinct populations of basal keratynocytes express stromelysin-1 and stromelysin-2 in chronic wounds. J. Biol. Chem. 94, 79-88.

Sato, H., Takino, T., Okada, Y., Cao, J., Shinagawas, A., Yamamoto, E. and Seiki, M. (1994). A matrix metalloproteinase expressed on the surface of invasive tumor cells. Nature 370, 61-65.

Taipale, J. and Keski-Oja, J. (1997). Growth factors in the extracellular matrix. FASEB J. 11, 51-59.

Varani, J. and Ward, P. A. (1978). A comparison of the migration patterns of normal and malignant cells in two assays systems. Am. J. Pathol. 90, 159172.

Wang, N., Butler, J. and Ingber, D. (1993a). Mechanotransduction across the cell surface and through the cytoskeleton. Science 260, 1124-1127.

Wang, N., Ingber, D. and Butler, J. (1993b). Magnetic probe reveals mechanical properties of cell. Focus 3, 3-4.

Wang, N. and Ingber, D. E. (1994). Control of cytoskeletal mechanisms by extracellular matrix, cell shape and mechanical tension. Biophys. J. 66, 2181-2189. 